\title{
14 A more experimental approach
}

ЕАCH OF THE six pieces in this chapter is ground breaking in its own way. The first, Pierre Schaeffer's 'Etude aux chemins de fer', represents one of the earliest experiments in electroacoustic music whereas in the second, U.S. Highball, Harry Partch uses a newly invented scale and newly invented instruments. 'Etude aux chemins de fer' is arguably the first piece of music to use sampling, and sampling is central to Steve Reich's politically motivated piece for string quartet and tape, Different Trains. In the remaining three pieces, The End of the Line (A Brief Encounter) by Peter Wiegold and Dominic Power, Gavin Bryars' The Stopping Train and John Cage's Il treno, the railway is not only the subject of the composition, it also serves as the performance venue itself. In five of the six pieces, the connection between the music and the train lies, to some extent, in the recreation of the rhythmic sounds of the railway. Cage's piece is different. Instead it could be argued that it is more about the atmosphere of the train journey, acting as an invitation to be aware of the sounds that are all around us. Random sounds are taken from the train and its environs and everyday sounds are juxtaposed with manufactured ones; the piece is unpredictable and full of possibilities, generating new auditory experiences and having the potential to transform the way we think about both music and listening.

\section{'Etude aux chemins de fer' (1948) - Pierre Schaeffer}

It is ironic that a central aim of the composer of one of the most groundbreaking railway pieces was that 'the train must be forgotten'. Thus wrote the French composer, acoustician and electronics engineer Pierre Schaeffer (1910- 
1995) of his pioneering piece 'Etude aux chemins de fer', the first of his Cinq études de bruits (Five studies of noises). These were the first pieces of musique concrete, a form of electroacoustic music where natural everyday sounds, rather than musical instruments, are recorded and then distorted by simple techniques of editing, reversal and speed changing. Schaeffer began his career at France's public broadcaster Radiodiffusion Française (RDF) in 1936. He persuaded the RDF to give him permission to begin experiments in music technology, researching into noise, and it was here, at the RDF Studio d'Essai that the five études were created.

'Etude aux chemins de fer' is a collage of sampled train sounds recorded at Batignolles station in Paris. The short work opens with the sound of a distorted train whistle followed by a succession of loops of the six engines puffing and chugging, slowed down, speeded up, superimposed, changing in volume, and all punctuated by transformed whistle sounds. One of the most significant developments was the idea of making loops of sound. Schaeffer used phonograph discs (he later started to use tape) and the loops were made by a studio technique referred to as the 'locked groove', where the disc was scratched so that it would play a sound in a perpetual loop.

Musique concrete demanded new ways of thinking and writing, as well as listening. Schaeffer wished to break the link between a sound and its cause. He argued that listening without reference shifted the listener's perception to other purely sonic attributes and he coined the term 'acousmatic' to describe a sound when its source is hidden.

I hope that one day there will come together an audience that prefers the theoretically less rewarding sequences, where the train must be forgotten and only sequences of sound color, changes of time, and the secret life of percussion instruments are heard. ${ }^{1}$

The works were first broadcast on 5 October 1948 with the title 'Concert de bruits' and were met with some hostility. Nevertheless, the importance of these pieces cannot be denied; they presented a new way of making music, manipulating and transforming sounds electronically, which has had a lasting influence. Schaeffer's ideas were central to electronic music and the work of such composers as Iannis Xenakis, Pierre Boulez and many others who followed. But Schaeffer's influence was to reach well beyond the field of contemporary art music. One of the most significant developments was the idea of making 
loops of sound and in doing so he effectively invented sampling - the mainstay of today's hip-hop and electronic dance music (EDM).

\section{Espace (Escape) (1989) - Francis Dhomont}

In the same year that Schaeffer composed 'Etude aux chemins de fer', the French composer Francis Dhomont (b. 1926) was also experimenting with electroacoustic music. Some forty one years later he used train sounds in his piece Espace (Escape) a poetic reverie on wandering. Espace (1989) is an acousmatic piece involving shifts of space, place and atmosphere. The sounds of trains, environments in railway stations and congregations of people are manipulated in the studio using different processors and then diffused through multiple speakers in performance.

\section{U. S. Higbball (A musical account of a transcontinental bobo trip) (1943, revised 1958) - Harry Partch}

Harry Partch (1901 - 1974), the American composer, instrument maker and performer, was born in California but grew up hearing musicfrom many cultures as he travelled around with his missionary parents. His musical inspiration and materials came from outside the European tradition and because of this he was ignored by most musical institutions. Partch rejected Western scales and invented his own which was made up of 43 notes in the octave rather than 12. He went on to devote his time implementing this system, having to create new instruments which could be tuned to this new scale and then training performers to play them. In his lifetime Partch was often considered to be simply eccentric, but since his death he has come to be recognized as one of the most innovative American composers of the twentieth century.

Much of his life was spent living on the margins of society. In 1935 at the height of the Great Depression he began a transient existence in the western states, jumping trains, sometimes living in boxcars in train yards, picking up work and occasionally obtaining grants from organizations en route. For several years he kept a journal, a small notepad that he used to transcribe 'fragments of conversations, remarks, writings on the sides of boxcars, signs in havens for 
derelicts, hitchhikers' inscriptions, names of stations, thoughts. ${ }^{2}$ These notes became the basis for U.S. Highball, a piece for speaker and Partch's instruments. In 1943 he started work on the first draft using the motley assortment of instruments he had built at that point. These included the Adapted Guitar (a guitar with new frets to accommodate his tuning system), the Chromelodeon (a re-tuned foot-pump harmonium), and the Kithara (his own version of the ancient Greek stringed instrument but now with 72 strings). Partch took the comments he had recorded in his notebook and turned them into melodies which matched the inflection and declamation of American English.

In Genesis of a Music, the book where the composer laid out his compositional and aesthetic treatise, Partch wrote that U.S. Highball was the 'most creative piece of work I have ever done'. The second version, which Partch preferred, was completed in 1958. New instruments were added which he had created over the previous ten years resulting in a more percussive sound. The instruments included a set of marimba-based instruments; a smaller version of the 72 string Kithara (Surrogate Kithara), and a collection of tuned artillery shells and Pyrex water containers (the Spoils of War). The work includes quotes from the hoboes such as "Wait for the next drag, there will be lots of empties on it. Too cold to ride outside this weather", "You'll get killed on that oil tank. There's an empty back here", "Ain't got no matches, ain't got no tobacco, ain't got no money. Is that blanket big enough for two?" "There she jumps again. That engineer don't know how to drive this train" and "Hey, don't sleep with your head against the end of the car! You'll get your neck broke when she jerks!" With the small intervals in his new system of tuning applied to both voice and instruments, sliding steam whistle sounds and the occasional percussive rhythm, U. S. Highball has a surreal atmosphere, but it is oddly reminiscent of a train journey.

Partch's composition uses fragments of speech transformed into melodies. Reich uses a similar technique in Different Trains by taking the pitches of small samples of speech and then transcribing them in musical notation to be played by a string quartet. 


\section{Different Trains (1988) - Steve Reich}

Steve Reich was born in New York in 1936. Having completed a degree in philosophy he went on to study composition with Luciano Berio and Darius Milhaud amongst others. Following this more conventional classical music education, he went on to study Balinese gamelan, African drumming and traditional forms of the chanting of Hebrew scriptures subsequently incorporating these non-Western elements into his music. In the 1960s, along with Terry Riley and Philip Glass, Reich discovered the tape-based techniques of phasing and looping. Some pieces included recordings of fragments of speech (Come Out and It's Gonna Rain, for example), others, such as Clapping Music, were based on fragments of musical material which were then 'phased. ${ }^{3}$ His music has influenced generations of pop, jazz and classical musicians.

Different Trains (1988) is in three movements played without a pause.

1. America - Before the war

2. Europe - During the war

3. After the war.

Reich writes in his programme note

The idea for the piece came from my childhood. When I was one year old my parents separated. My mother moved to Los Angeles and my father stayed in New York. Since they arranged divided custody, I travelled back and forth by train frequently between New York and Los Angeles from 1939 to 1942 accompanied by my governess. While the trips were exciting and romantic at the time I now look back and think that, if I had been in Europe during this period, as a Jew I would have had to ride very different trains. With this in mind I wanted to make a piece that would accurately reflect the whole situation.

In order to prepare the tape I did the following:

1. Record my governess Virginia, then in her seventies, reminiscing about our train trips together.

2. Record a retired Pullman porter, Lawrence Davis, then in his eighties, who used to ride lines between New York and Los Angeles, reminiscing about his life. 
3. Collect recordings of Holocaust survivors Rachella, Paul and Rachel, all about my age and then living in America-speaking of their experiences.

4. Collect recorded American and European train sounds of the '30s and '40s.

In the first movement, Reich's governess and the Pullman porter Lawrence Davis, reminisce about train travel in the USA while American train sounds are heard in the background. European train sounds and sirens are heard in the second movement. Three Holocaust survivors speak about their experiences in Europe during the war, including travelling to concentration camps by train. In the third movement the Holocaust survivors talk about the years immediately following World War II, alongside recordings of Davis and Virginia and a return to the American train sounds from the first movement.

Reich selected small samples of speech that used fairly clear pitches and then transcribed them as accurately as possible in musical notation. This was to be played by the strings, so in effect, the strings imitate the melodies of the speech. In Reich's words 'The piece thus presents both a documentary and a musical reality and begins a new musical direction'. Reich used Casio FZ-I and FZIoM samplers to manipulate and play the fragments of speech. In the same way the train sounds, sirens and bells are sampled and edited and incorporated into the scheme of the music. So, for example, the repeated semiquavers of the string writing are coupled to the clatter of trains. ${ }^{5}$

The British composer and musicologist Christopher Fox observes that the 46 spoken phrases are the most remarkable feature of the work.

...through them Reich is attempting nothing less than a brief history of perhaps the most appallingly systematic onslaught, in this or any other century, by a government on the lives of millions of people. By focussing on the personal histories of a few individuals he is able to emphasize the inhumanity of the Nazis' invasion of so many people's lives; the juxtaposition of the two Americans with their European contemporaries establishes the contrast between normality and the Europeans' experiences. Thus when the Pullman porter, Lawrence Davis, says in the third movement, 'But today, they're all gone', he is recalling the luxurious transcontinental trains on which he worked; however, for the listener, these words can also become an elegy for the millions of people who died between 1933 and 1945.

In the final movement Reich addresses what Fox describes as 'one of the fundamental questions posed by the Holocaust: how is it possible that the 
same music can be enjoyed by both oppressed and oppressor?' Rachella, the Holocaust survivor describes how "There was one girl, who had a beautiful voice, and they loved to listen to the singing, the Germans, and when she stopped singing they said, "More, more" and they applauded'.

The world premiere of Different Trains for string quartet and pre-recorded tape took place in 1988. Following its UK premiere, Paul Griffiths, writing for The Times, described it as a 'quite astonishing new piece'.

It is entirely new in its voice-instrument fusions, and in the further fusions with the recorded train noises, notably sirens and whistles. It is new too in its rapid, railroad-paced changes of tonality, effected stunningly in the middle section by glissandos along lines laid out by the sirens. In this section there is also the dizzying impression of a whole network of musical traffic behind the main train, with chains of repeating figures being switched through points, appearing from and vanishing into silence.

In the following three pieces the railway is central, not only for its sounds, but also for its performance venue. In his piece 'From Hanover Square North', Charles Ives' recalls his experience when crowds waiting on the station platform broke into the spontaneous singing of a hymn on the day that the news broke of the sinking of the RMS Lusitania (see pages 157 - 59). The first piece in this group is resonant of this memory, a bittersweet event taking place in a station amongst large crowds.

\section{The End of the Line (A Brief Encounter) - Peter Wiegold composer and Dominic Power libretto}

On July 4, 2009, 150 musicians and eight solo singers from the Royal Northern College of Music took part in a musical installation at Piccadilly Station in Manchester. Under the direction of the composer Peter Wiegold, and with a libretto by Dominic Power, the students mingled amongst an audience of commuters, clubbers and late-night travellers to perform a new piece, The End of the Line (A Brief Encounter). The piece paid homage to the 1945 film Brief Encounter, famous for its romantic scenes set in a railway station (filmed on location at Carnforth), not least the heart-rending scene when the couple part for the last time. The eight singers, dressed in 1940s fashion, made up four 
couples who were parting and saying their farewells. The station clock has stopped and they are frozen in a moment of time as their memories flash by.

All in all there were two string orchestras, two brass bands, percussion, a group of clarinets and saxophones playing repeated rhythmic figures reminiscent of a train, and a bank of harps adding a romantic note. The groups of musicians were sited at various parts of the station - the singers on podiums, woodwind and brass on the gallery, some amongst the audience - several with their own conductors dressed as railway guards. Layers of sound, exploiting the sonic potential of the vast space of the station, produced, at times, a magnificent cacophony. As the work came to an end and the music died away, one train sounded a long note on its horn as the singers disappeared, one by one, down the long platform.

\section{The Stopping Train (2018) - Gavin Bryars and Blake Morrison}

In 2016 the Yorkshire Festival and Sound UK commissioned Gavin Bryars and Blake Morrison to create an audio work to be listened to on the train journey from Goole (Bryars' birthplace) to Hull. Morrison reads his own poems and members of the Gavin Bryars Ensemble play the music. While Morrison's poetry describes the journey, musing on the area's history and geography, the music underscores the texts. The ten tracks are timed to coincide with each of the five stops along the route in both directions and are composed for headphone-wearing passengers as they gaze out of a train window. Stuart Jeffries took the journey and describes it thus.

The words are accompanied by the viola, cello and bass of the Gavin Bryars Ensemble, with an electric guitar mournfully wailing like a train whistle as we roll beneath grey skies through a captivatingly lugubrious landscape of low-lying sheep fields and windfarms...says he thinks of his native land as a melancholy place. "Despite or perhaps because of that, it has its fascinations," he says. ${ }^{8}$ 


\section{Alla Ricerca del Silenzio Perduto (In Search of Lost Silence) 1978 - Jobn Cage}

On June 26, 1978 a three-day event began in Bologna Centrale Station with the title Alla Ricerca del Silenzio Perduto. A stopping train filled with passengers, musicians and electronic music equipment embarked on its journey through the north-eastern Italian region of Emilia-Romagna making stops at designated towns. Passengers were greeted at the station by bands and dancers from the surrounding area, speakers relayed sounds from the local environment, and cassette recorders played unexpected sounds in random corners.

The shorter version of the title was Il Treno di John Cage. The piece had been inspired by John Cage (1912 - 1992): experimental composer, inventor of the prepared piano, champion of chance music and pioneer of the happening, the man who claimed that anything and everything was music. In a Seattle lecture Cage once said

Everything we do is music. Wherever we are, what we hear is mostly noise. When we ignore it, it disturbs us. When we listen to it, we find it fascinating. The sound of a truck at 50 miles an hour. Static between the stations. Rain. We want to capture and control these sounds, to use them, not as sound effects but as musical instruments.?

He challenges our preconceptions of what music is and dares us to imagine what it might be. In his most (in)famous piece, 4'33" (1952), the so-called 'silent piece', he asks the performer(s) to do nothing for the specified time, inviting the audience to be aware of the beauty of the sounds that are all around us. ${ }^{10}$ Similarly, in capturing and controlling the sounds of the train and its environs in Alla Ricerca del Silenzio Perduto we are invited to listen in a different way.

Some have compared the way Cage uses the train as an instrument to his 'prepared piano', an instrument he invented where, by placing a variety of objects between the strings, it is transformed into something sounding more like a large percussion ensemble. The event did indeed take a good deal of preparation. The train was equipped with internal and external speakers. Sixteen microphones were placed in and around the wagons to gather the sounds of the train, the squeaks, the rattles and rhythms of the railway. Once collected the sounds would be amplified and mixed by Cage and his assistants and then sent through the speakers - one set per car. Video-cameras and screens were installed in the 
wagons, so that people could see what was happening in the other cars. As well as seven passenger cars, the train was equipped with a car for sound mixing to take place and one for the electricity supply. Throughout the journey musicians would walk around the train playing music and at each stop previously recorded sounds would be played through the external speakers.

Martin Friedman, the curator of the Walker Art Center in Minneapolis was aboard the train. Reminiscing about the event he writes that Cage had agreed to come to Bologna where Tito Gotti, the Bolognese impresario who had put forward the idea of the event, introduced him to the composers Walter Marchetti and Juan Hidalgo and then set about choosing the right train. As part of the audition process they decided to look for simple cars, not every train

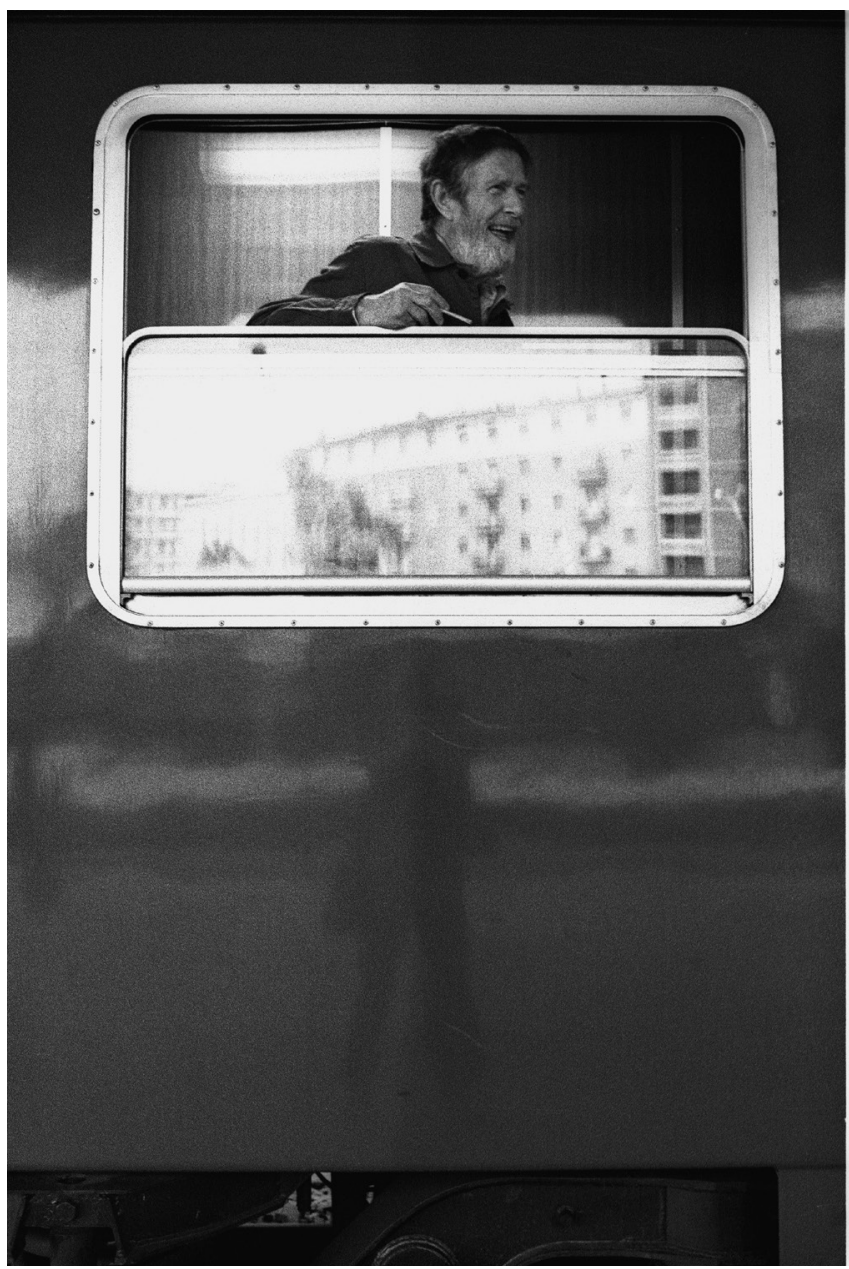

John Cage aboard Il Treno di John Cage, 1978

(C) Photograph Corinto Marianelli 
would qualify. The plan was for the passengers to 'experience the juxtapositions of man-made and mechanically generated sound, unexpected sounds could be coaxed from parts of the auditory mix; nothing was sacred.' Two cars without compartments were used to house the chamber ensembles. At each of the stops the train was greeted by local people, bands, folk dance groups, and other ensembles creating a carnival-like atmosphere. Friedman writes 'As the picturesque ... panorama of tile-roofed villages and verdant farmland rolled by, passengers could switch channels to hear amplified train noises or prerecorded music from the towns and villages where the train stopped'. Some of the musicians strolled round the cars with performers ranging from mime artists to vocalists. The first stop was at the little town of Riola where they were greeted by crowds and musician: the local police band played marches; choral music and folk songs were sung by the alpine infantry corps in feathered caps; and a village orchestra played romantic waltzes. News of the musical event spread up and down the lines the train would travel over in its three excursions with many more joining in the festivities. ${ }^{11}$

How did the event end? In its preview of the happening, the Italian newspaper l'Unità reported that

During the return trip there will be no stops. The trip will be accompanied by the sound of the train only. Finally, when the train comes to a complete stop, we will hear the sounds of the station at night: empty and calm; and we will find the Lost Silence. ${ }^{12}$ 


\section{Endnotes}

1 Pierre Schaeffer. In Search of a Concrete Music, trans. Christine North and John Dack. (Berkeley and Los Angeles: University of California Press, 2012): 14.

2 Andrew S Grenade. "U. S. Highball (A Musical Account of a Transcontinental Hobo Trip). Harry Partch; Gate 5 Ensemble (1958)", 2004. https://www.loc.gov/static/programs/nationalrecording-preservation-board/documents/USHighball.pdf, 1.

3 Phase shifting (or phasing) is where one part repeats constantly and another gradually shifts out of phase with it.

4 Reproduced by kind permission of Boosey \& Hawkes.

5 Christopher Fox. Steve Reich's 'Different Trains' in Tempo, Mar., 1990, New Series, No. 172 (Mar., 1990): 6.

6 Fox, 'Different Trains', 8.

7 The Times, Nov. 3, 1988.

8 The Guardian, 14 April, 2018.

9 John Cage. Silence. Lectures and writings by John Cage. (Middletown: Wesleyan University Press, 1961).

10 Barry Russell. Everything we do is music: Cross-curricular experiments in sound based on the music of John Cage. (London: Peters Edition, 2016).

11 https://walkerart.org/magazine/il-treno-di-john-cage-happening-on-wheels

12 L’Unità, May 23, 1978. 